\title{
Seismic hazard assessment of existing reinforced concrete bridge structure using pushover analysis
}

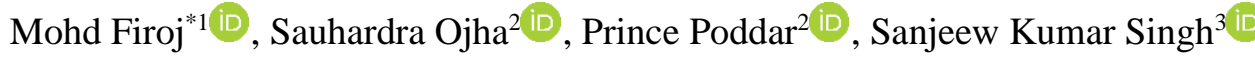 \\ ${ }^{1}$ Indian Institute of Technology, Roorkee, India \\ ${ }^{2}$ Dr. Rammanohar Lohia Avadh University, Institute of Engineering and Technology, Ayodhya, India \\ ${ }^{3}$ CSIR-Central Building Research Institute, Roorkee, India
}

\begin{abstract}
The present paper focuses on the nonlinear static pushover analysis of a 3-span existing RC bridge located in Indian seismic Zone IV as per IS1893-2016 using the Finite Element Method (FEM). The 3D model of the RC bridge is simulated using the FEM technique and pushover analysis is performed to analyze the structure for modal mass participating ratio, performance level, spectral demand, and capacity of the structure. The bridge pier and longitudinal girder are modeled using the two noded beam element and bent cap and abutment of the bridge structure is modeled using the 8 noded brick element. The base of the column is assumed fixed condition. The pushover analysis is performed using Displacement Modification (FEMA 440) and Capacity Spectrum Method (ATC 40). The outcomes of results appear that the considered bridge has inadequate capacity to cope up with any of the desired performance levels because spectral demand is greater than the spectral capacity. The modal analysis of the 3D bridge exposes that it has many closelyspaced modes. The mass participating ratio for the higher modes is not very high. After performing pushover analysis of the exiting RC bridge structure it has been concluded that the existing bridge structure does not meet seismic criteria of spectral demand as per the ATC 40 and FEMA 440, therefore retrofitting is required for bridge component i.e. piers, abutment, and bent cap.
\end{abstract}

\section{Keywords}

Pushover analysis; RC bridge; Spectral capacity; Spectral demand; ATC 40; FEMA 440

Received: 18 September 2020; Accepted: 05 November 2020

ISSN: 2630-5763 (online) C 2020 Golden Light Publishing All rights reserved.

\section{Introduction}

Over the last ten decades, India has challenged the world's major earthquake. The north-eastern part of India along with the Himalayan region is vulnerable to crucial earthquakes having magnitude 8.0 or even more. Bridges play a major role in the development of the nation as they connect two remote areas, nowadays it is also useful in traffic control, Failure of a single bridge leads to not only huge monetary loss but also human life's, which is precious than anything. Researchers show that RC curved bridges can collapse from the structural configuration and design principle [1]. The major collapse in the pier of the Baihua Bridge was either shear flexural or the pure shear case as shown in Fig. 1 [2] observed that all the concrete stopper on pier cap gets crushed as shown in Fig. 2. The author also observed that in the Nisqually Earthquake of 0.3 seconds, the concrete pier of the bridge was damaged at the base and concrete spalling was also

* Corresponding author

Email: mohdfiroj2493@gmail.com 
found in the piers as shown in Fig. 3. Therefore, it is very relevant to check the vulnerability of existing bridges for seismic forces. A vulnerability of the existing bridge structure can be checked using the pushover analysis. Therefore, the next paragraph gives a brief description of the pushover analysis.
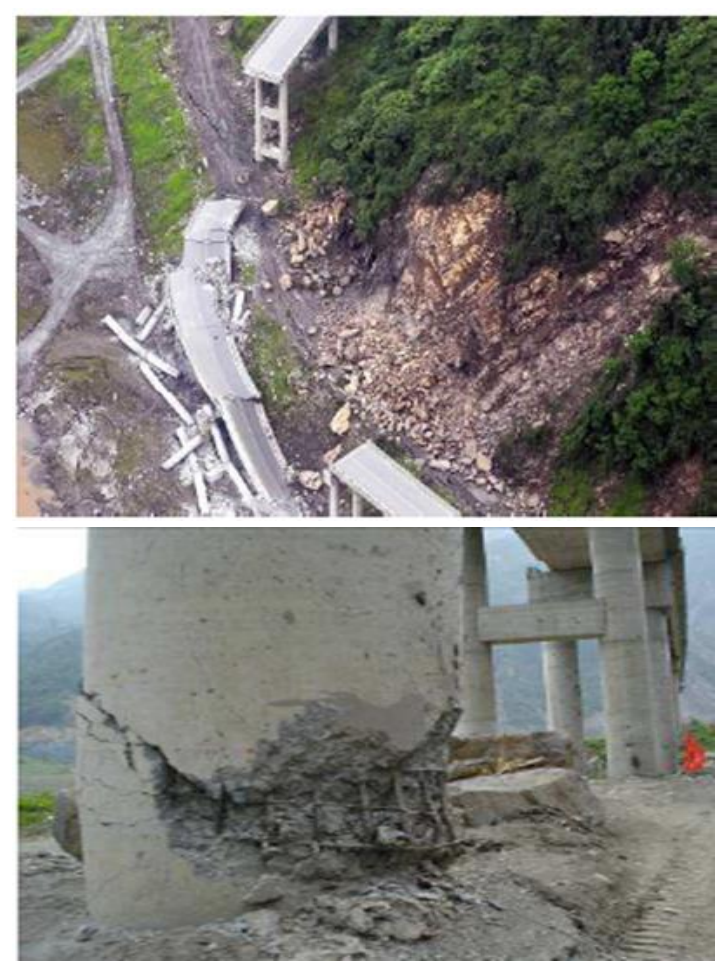

Fig. 1. Failure of a column of Baihua Bridge

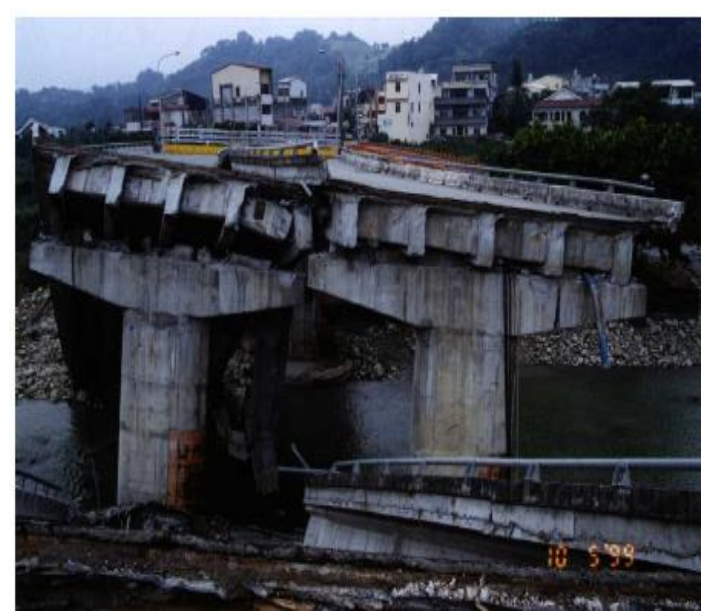

Fig. 2. Crushed concrete stopper on pier cap

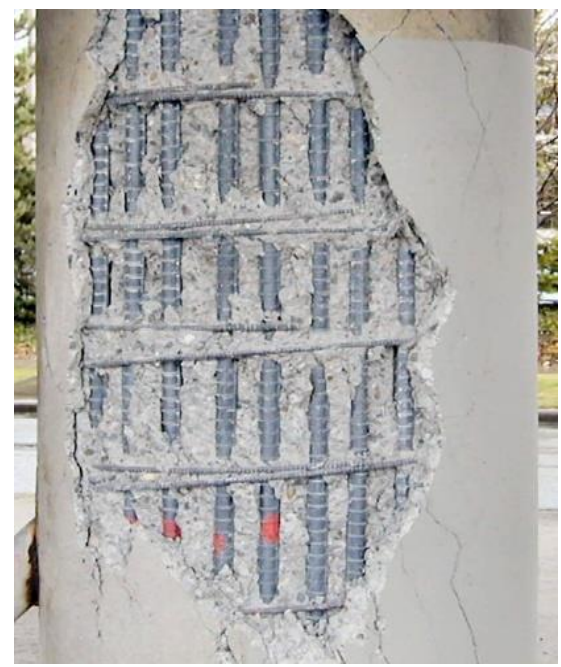

Fig. 3. Damaged column

Pushover analysis is a nonlinear static analysis in which the lateral force is applied monotonically for the required performance level. Sequential failure, plastic hinging, and cracking patterns are estimated in pushover analysis. The role of pushover analysis for structures issued since the 1970 s, however, it is used widely in the last $15-20$ years. Pushover analysis is used to find out the strength and actual displacement of an existing structure during seismic ground motion. This analysis is also useful for verification and adequacy of new structural design as well. Researchers developed the modal pushover analysis to calculate the seismic performance in a nonlinear system which comprises of two stages i.e. (i) the peak response of the inelastic multi-degree of freedom system and (ii) total demand by combining modal combination [3]. Ranjit et al. [4] investigated the first pier hinging for nonlinear equilibrium conditions during the required performance level. In preference of employing various demand spectra with distant damping ratios, the feat point is accessed by the intersection of capacity spectrum and a single demand spectrum with different damping. This spectrum curve is obtained with a procedure similar to the method called procedure $\mathrm{B}$ in chapter 8 of ATC-40 [5]. Modeling of hinges uses the "P-M2-M3 Type hinge" instead of the "M3-Type" hinge for the reinforced column [6]. 
Kappos et al. [7,8] showed that the standard pushover analysis provides a better result only in the dominated first mode while the modal pushover analysis provides the result by combining various modes. Banerjee and Shinozuka [9] showed that the nonlinear static analysis method provides more practice-oriented results than nonlinear dynamic analysis in evaluating the seismic performance of the bridge. Researchers observed that for the multispan bridge, the performance of modal pushover analysis in nonlinear range follow the similar behavior as in linear range, although the mode shape is different in yielding [10]. Range Pinho et al. [11] explained that the first mode pushover analysis is able to predict the response of continuous span bridges subjected to seismic loading. Paraskeva et al. [12] proposed a Modal Pushover Analysis, which improves the accuracy in determining the deck displacement in the higher modes. In the nonlinear demand spectrum method, the seismic demand is much more difficult to define unless a simplified inelastic design spectrum is utilized. Pushover analysis based on uniform loading pattern is failed to capture the maximum displacement at the center of gravity of the structure [13]. Paraskeva and Kappos [14] showed that in the case of the overpass of the bridge, modal pushover analysis, standard pushover analysis, and response history analysis follow the closer value of maximum deck displacement. Tehrany et al. [15] found that the spectral displacement capacity of the bridge decreased on an average by $43 \%$ also spectral displacement demand decrease when loose sand is replaced by dense sand. Hence, by combining both effects, the author concluded that loose sand represents the worst-case scenario. Beheshti and Jahanfekr [16], introduced a new correction coefficient $\mathrm{CB}$ for the regular bridge which is multiplied by the previous coefficient. Although further investigation is required for the irregular bridge. Ojha et al. [17] carried out a pushover analysis of a 10 story reinforced framed concrete structure and check the vulnerability of the building component. Patil et al. [18] find out the seismic capacity of a typical $\mathrm{T}$ girder concrete highway bridge designed as per Indian standards code studied different girder bridges subjected dynamic load to investigate the seismic risk assessment. Murdiansyah et al. [19] investigate the seismic performance of Wreksodiningrat arch bridge, using nonlinear modal pushover analysis. Maheshwari and Firoj [20] develop the springdashpot model for the lumped mass structure. Bergami et al. [21] reported that nonlinear static pushover analysis is a powerful tool to predict the displacement behavior of existing bridges.

From the above literature, it is found that many of the existing bridges were failed during past earthquakes. Therefore, the existing bridge structure should be checked against the new code for rehabilitation purposes. Keeping in view the above literature, it is found that very few studies are carried out for the seismic demand of existing bridge structure using the pushover analysis. Therefore, this paper emphasis to develop the numerical finite element model of the existing bridge structure using two different code i.e. ATC 40 [5] and FEMA 440 [22] for the retrofitting purposes.

\section{Method of analysis}

The analysis of the existing bridge structure is carried out using the two standard code approaches i.e. capacity spectrum method and displacement modification method.

\subsection{Capacity spectrum method (ATC 40)}

The capacity spectrum method (CSM) is a technique to draw the push-over curve for determining the performance point sometimes also called the ADRS (Acceleration-Displacement Response Spectra) method of the structure. It qualifies the spectral demand initially using a 5\% damped linear-elastic response spectrum and diminish the spectrum to send back the effects of energy dissolution to access the inelastic displacement demand.

To convert a spectrum from the standard $\mathrm{Sa}$ (Spectra Acceleration) vs. $T$ (Period) format found in the building codes to ADRS format, it is necessary to determine the value of $S d_{i}$ (Spectral 
Displacement) for each point on the curve, $S a_{i}, T_{i}$. This can be done with Eq. (1) as

$S d_{i}=\frac{T_{i}^{2}}{4 \pi^{2}} S a_{i} g$

Standard demand response spectra contain a range of constant spectral acceleration and the second range of constant spectral velocity, $S_{v}$. Spectral acceleration and displacement at a period $T_{i}$ are calculated using Eq. (2):

$S a_{i} g=\frac{2 \pi}{T_{i}} S_{v}, \quad S d_{i}=\frac{T_{i}}{2 \pi} S_{v}$

The seismic capacity is calculated using first mode spectral coordinates. Any point $V_{i}$ (Base Shear), $\delta_{i}$ (Roof Displacement) on the capacity (pushover) curve is converted to the corresponding point $S a_{i}, S d_{i}$ on the capacity, spectrum using the Eqs. (3) and (4) respectively,

$S a_{i}=\frac{V_{i} / w}{\alpha_{1}}$

$S d_{i}=\frac{\delta_{i}}{\left(P F_{1} \times \phi_{1, \text { roof }}\right)}$

where, $\alpha_{1}$ and $P F_{1}$ are the modal mass coefficient and participation factors for the first natural frequency of the structure respectively. $\phi_{1, \text { roof }}$ is the top-level amplitude of the first mode. The modal participation factors and modal coefficient are given in Eqs. (5) and (6):

$P F_{1}=\left[\frac{\sum_{i=1}^{n}\left(w_{i} \phi_{i 1}\right) / g}{\sum_{i=1}^{n}\left(w_{i} \phi_{i 1}^{2}\right) / g}\right]$

$\alpha_{1}=\frac{\left[\sum_{i=1}^{n}\left(w_{i} \phi_{i 1}\right) / g\right]^{2}}{\left[\sum_{i=1}^{n} w_{i} / g\right]\left[\sum_{i=1}^{n}\left(w_{i} \phi_{i 1}^{2}\right) / g\right]}$

where $w_{i}$ is the weight at any level $i$.

The damping at the time of pushover analysis in the plastic range is the combination of viscous and hysteretic damping. Hysteretic damping can be represented as equivalent viscous damping. Thus, the total effective damping can be estimated using Eq. (7):

$\beta_{\text {eff }}=\lambda \beta_{o}+0.05$

where $\beta_{o}$ is the hysteretic damping and 0.05 is the assumed and 5\% viscous damping inherent in the structure is assumed. The $\lambda$-factor (called $\kappa$-factor in ATC-40) is a modification factor to account for the extent to which the actual building hysteresis is well represented by the bilinear representation of the capacity spectrum.

The hysteretic damping can be calculated using Eq. (8):

$\beta_{o}=\frac{1}{4 \pi} \frac{E_{D}}{E_{S o}}$

where $E_{D}$ is the energy dissipated by damping and $E_{S o}$ is the maximum strain energy.

\subsection{Displacement modification method (FEMA 440)}

The displacement modification method includes several improved alternatives for the basic ratio of the maximum displacement (elastic plus inelastic) for an elastic perfectly plastic SDOF oscillator to the maximum displacement for a completely linear elastic oscillator that is designated as the coefficient $C_{1}$ in FEMA 356. This method also recommends that the current limitations (capping) allowed by FEMA 356 to the coefficient $C_{1}$ be abandoned. Besides, a distinction is recognized between two different types of strength degradation that have different effects on system response and performance. This distinction leads to recommendations for the coefficient $C_{2}$ to account for cyclic degradation in strength and stiffness. It is also suggested that the coefficient $C_{3}$ can be eliminated.

For most structures, Eq. (9) may be used for the coefficient $C_{1}$ :

$C_{1}=1+\frac{R-1}{a T_{e}^{2}}$

where, $T_{e}$ is the effective fundamental period of the SDOF model of the structure in seconds and $R$ is the strength ratio computed in FEMA 356 method. The constant $a$ is equal to 90 for the medium soil condition. For periods less than $0.2 \mathrm{~s}$, the value of the coefficient $C_{1} 0.2 \mathrm{~s}$ may be used. For periods greater than $1.0 \mathrm{~s}, C_{1}$ can be assumed to be 1.0 .

It is recommended that the $C_{2}$ coefficient can be calculated using Eq. (10)

$C_{2}=1+\frac{1}{800}\left(\frac{R-1}{T}\right)^{2}$ 
For a period less than $0.2 \mathrm{sec}$, the coefficient $C_{2}$ for $0.2 \mathrm{~s}$ may be used. For periods greater than 0.7 sec, $C_{2}$ may be assumed equal to 1.0 .

\section{Modeling of RC bridge}

In the present study, the RC bridge is modeled using the FEM. The pier of bridge and longitudinal girder is modeled using 2 noded beam element while the bent cap and abutment are modeled using the 8 noded brick element. The concrete behavior is modeled using Mander's model. The reinforced concrete bridge considered in the study is a 3-spans, two-lane bridge having a $9 \mathrm{~m}$ width and $30 \mathrm{~m}$ span, supported by a $\mathrm{T}$ shape girder having $1.5 \mathrm{~m}$ total depth. The longitudinal girders are supported on the bent cap over the fixed bearing and latch in a transverse orientation. The load-bearing piers are circular having $1 \mathrm{~m}$ diameter, fixed at the bottom, and of height $8 \mathrm{~m}$. The end of the span is supported by the abutment having the size of $15 \times 2 \mathrm{~m}$. IRC $70 \mathrm{R}$ design live load is considered in the analysis for assessing the performance of the existing $\mathrm{RC}$ bridge structure [23]. The mechanical properties of the RC bridge structure considered are shown in Table 1. The base shear force is calculated for the bridge using the IRC 6-2014 [24] code and IS 18932016 [25] as reported by the various researchers [26-28] and Medium soil type is used for calculating the $\mathrm{Sa} / \mathrm{g}$ (spectrum acceleration) value.
The simplified figure of the bridge in the lengthwise direction is modeled using FEM as shown in Fig. 4. 20 bar having a diameter of $24 \mathrm{~mm}$ is provided in the longitudinal direction while transverse reinforcement is provided $10 \mathrm{~mm}$ diameter@100 mm spacing. Pier cross-section is circular and reinforcement details are in Fig. 5. The dimension and the pier deck arrangement as shown in Fig. 6 respectively. The possible hinge can be formed at the bottom and top of the pier, bent cap, and at the joint of the longitudinal girder with bent cap and abutment [29].

Table 1. Material properties of the bridge component

\begin{tabular}{clc}
\hline Sl. No. & Parameter & Values \\
\hline 1 & Modulus of elasticity, E (GPa) & $5000{ }_{\mathrm{f}_{\mathrm{ck}}}$ \\
2 & Poisson's ratio of concrete, $v$ & 0.2 \\
3 & Compressive strength of & 30 \\
& concrete (MPa) & Fe415 \\
4 & Grade of reinforcement (MPa) & 1.2 \\
5 & Importance factor (I) & 5 \\
6 & Response reduction factor (R) & $\mathrm{IV}$ \\
7 & Seismic zone & 0.24 \\
8 & Zone factor & Medium \\
9 & Soil type & $5 \%$ \\
10 & Damping ratio &
\end{tabular}

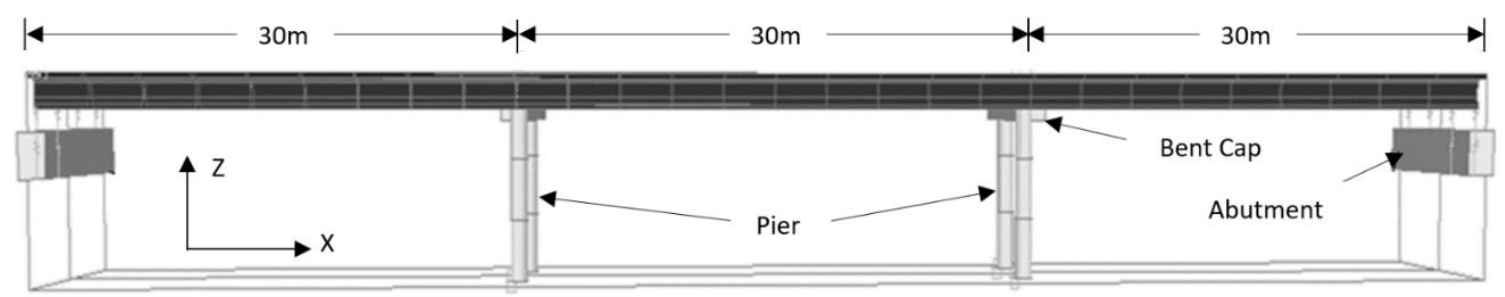

Fig. 4. Schematic diagram of the bridge in $X-Z$ plane 


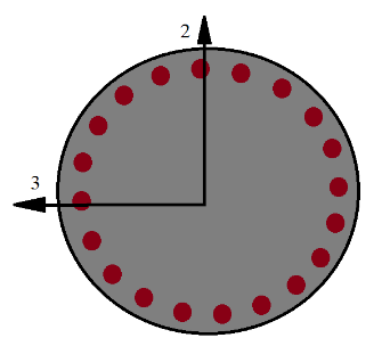

Fig. 5. Detail of pier section

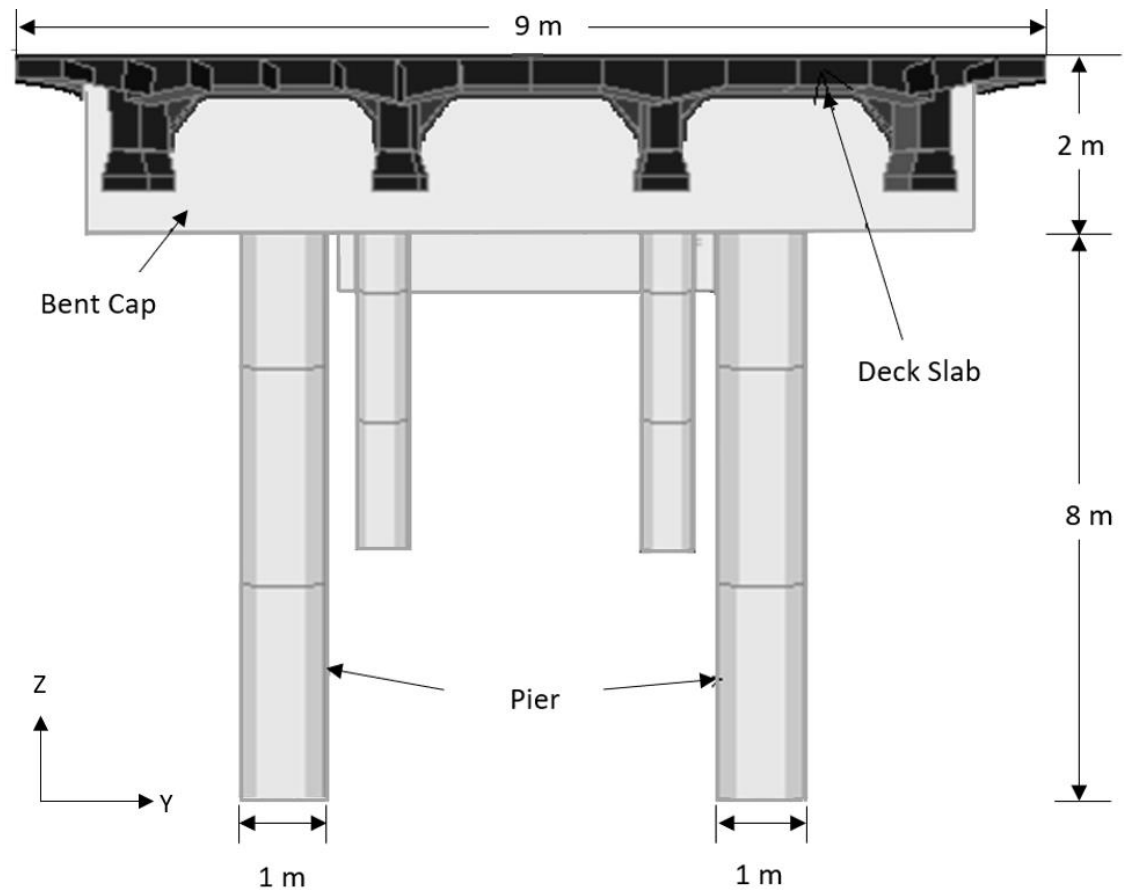

Fig. 6. Cross-section of the bridge in $\mathrm{Y}-\mathrm{Z}$ plane

\subsection{Modeling of flexural plastic hinges}

For performing the pushover analysis, the bridge modeling is taken out in such a manner that it assesses the inelastic behavior of the structural unit. In the present analysis, a point-plasticity way is advised to create inelasticity, at which point the plastic hinge is assumed to be concentrated at a particular point in the frame member under consideration. Piers in this study are modeled with flexure (P-M2-M3) hinges and longitudinal girder with (M3) plastic hinge at possible plastic regions under lateral load. The flexural hinges and the shear hinges for both ends of the longitudinal girders and piers are presented in Fig.7.
Flexural hinges which are based on material nonlinearity are defined, the behavior between the moment and rotation curve. The flexural hinges are depending on the reinforcement detailing and the cross-section for the location of the hinge. The hinges formed due to geometrical nonlinearity are obtained by the moment versus curvature behavior of the structural elements. For flexure hinges observed in pier was obtained in axial force interaction while the rotational values obtained, only by the axial force which is generated by the gravity load. 


\subsection{Moment vs. rotation criterion in the pushover analysis}

To model hinges, the moment- rotation parameter represents the basic input and this can be obtained between moment and curvature relation [30]. The idealized behavior between the moment and curvature is shown in Fig. 7. The important points between the moment and rotation curve are explained as:

- 'A' represented the unloaded condition.

- 'B' shows the behavior between the nominal elastic strength and the yield rotation $\left(\theta_{\mathrm{y}}\right)$.

- The 'IO' corresponds to the immediate vehicular performance level.

- The mark 'LS' corresponds to the life safety performance level.

- The mark 'CP' corresponds to prevent the structure from collapse.

- 'C' represents the behavior between the ultimate strength and ultimate rotation $\theta_{\mathrm{u}}$, later which failure takes place.

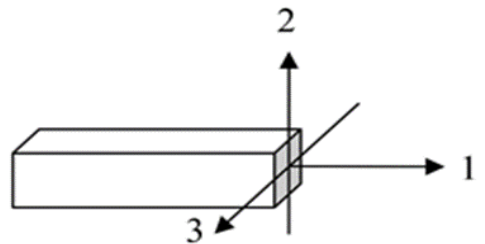

Fig. 7. Axis system for flexural and shear hinges

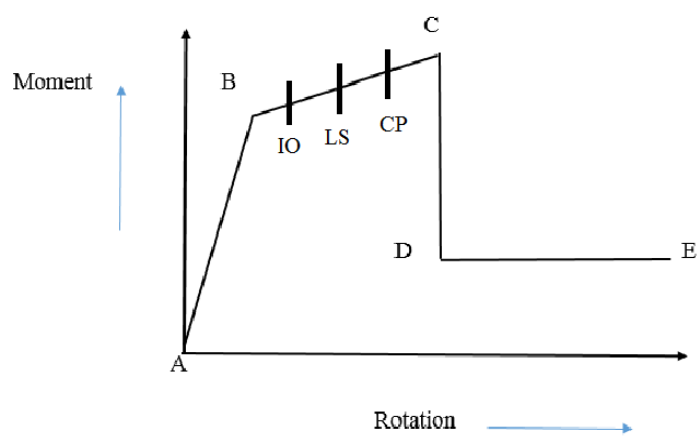

Fig. 8. The behavior between the moment and rotation curve of the RC component

- 'D' represents the residual strength of the element, if observed in the element, corresponds to the residual strength, if any, in the member.
- ' $E$ ' represents the maximum deformation capacity, which is considered as $15 \theta_{\mathrm{y}}$ or $\theta_{\mathrm{u}}$, whichever is greater.

\section{Results and discussion}

In the present study, the seismic performance of the actual RC bridge is calculated using pushover analysis. The analysis involves the estimation of modal mass participating ratio, the performance level of structure, spectral capacity, and spectral demand. The analysis is performed at the collapse prevention level for which the maximum drift at the top of the structure is $4 \%$ height of the structure i.e. $320 \mathrm{~mm}$.

\subsection{Modal mass participating ratio}

The vertical distribution of lateral forces or story shear which is incorporated in the equivalent static analysis (allows only when more than $75 \%$ of the total mass engage in the fundamental mode in the considered direction). Results of the modal mass participating ratio for different mode is shown in Table 2. The model mass participation factor is calculated in the cumulative sense. Based on the results, it is observed that the modal mass ratio is greater than $75 \%$ in the higher mode only in the $\mathrm{Z}$ direction.

\subsection{Performance point using ATC 40}

The demand displacement in the capacity spectrum method occurs at a mark, on the capacity spectrum which is called the performance point. Performance point represents the condition at which the seismic capacity of the structure is equal to the seismic demand imposed on the structure by the specified ground motion. The analysis is performed in two directions one is longitudinal and another is the transverse direction of the bridge. The longitudinal direction is denoted by the $\mathrm{X}$ direction and the transverse direction is denoted by the $\mathrm{Y}$ direction.

\subsubsection{Performance point in the $\mathrm{X}$ direction}

Results of the pushover demand \& capacity in the $\mathrm{X}$ direction are shown in Table 3 and graphical representation is shown in Fig.9. From the results, 
it is found that the maximum base shear is $1370 \mathrm{kN}$ at the maximum displacement of $25 \mathrm{~mm}$ whereas the spectral acceleration $\left(\mathrm{S}_{\mathrm{a}}\right)$ and the spectral displacement $\left(\mathrm{S}_{\mathrm{d}}\right)$ based on the ADRS format are $0.613 \mathrm{~g}$ and $25 \mathrm{~mm}$ respectively for $\mathrm{T}_{\mathrm{eff}}=0.4 \mathrm{sec}$. The effective damping $\beta_{\text {eff }}$ is 0.163 which is more than the conventional value 0.05 , it shows that structures have more ductility than what we have assumed. The spectral capacity and the spectral demand are found to be $24.5823 \mathrm{~mm}$ and 24.6375 $\mathrm{mm}$ respectively at $\mathrm{T}_{\text {eff. }}=0.4 \mathrm{sec}$ as estimated from Fig.10.

Table 2. Modal mass participating ratio

\begin{tabular}{ccccc}
\hline & \multicolumn{4}{c}{ Modal participating mass ratios } \\
\hline \multirow{2}{*}{ Step Type } & Period (Second) & \multicolumn{3}{c}{ Percentage participation ratio (\%) } \\
\cline { 3 - 5 } & & $\mathrm{X}$ & $\mathrm{Y}$ & $\mathrm{Z}$ \\
\hline Mode 1 & 0.16013 & 58.19 & 52.60 & 69.74 \\
Mode 2 & 0.14657 & 58.19 & 65.68 & 80.16 \\
Mode 3 & 0.09053 & 58.19 & 73.53 & 80.17 \\
Mode 4 & 0.08814 & 47.17 & 73.53 & 80.17 \\
Mode 5 & 0.08457 & 47.17 & 73.54 & 80.17 \\
Mode 6 & 0.08012 & 70.30 & 73.54 & 80.17 \\
Mode 7 & 0.07930 & 70.30 & 73.90 & 80.20 \\
Mode 8 & 0.07674 & 70.30 & 73.91 & 80.29 \\
Mode 9 & 0.06487 & 70.30 & 73.99 & 80.30 \\
Mode 10 & 0.05483 & 70.30 & 74.02 & 80.36 \\
Mode 11 & 0.05430 & 70.30 & 74.07 & 80.37 \\
Mode 12 & 0.04132 & 70.30 & 74.07 & \\
\hline
\end{tabular}

Table 3. Demand and capacity in the $\mathrm{X}$ direction

\begin{tabular}{ccccc}
\hline \multicolumn{4}{c}{ Demand and capacity in the X direction } \\
\hline S. No. & $T_{\text {eff }}($ Second) & $\beta_{\text {eff }}$ & Spectral displacement $\left(\mathrm{S}_{\mathrm{d}}\right)$ \\
& & & Capacity $(\mathrm{mm})$ & Demand $(\mathrm{mm})$ \\
\hline 0 & 0.32133 & 0.050 & 0.00 & 25.65 \\
1 & 0.32133 & 0.050 & 1.46 & 25.64 \\
2 & 0.32111 & 0.050 & 2.77 & 25.61 \\
3 & 0.31799 & 0.050 & 10.89 & 25.19 \\
4 & 0.31819 & 0.050 & 10.94 & 25.15 \\
5 & 0.34584 & 0.105 & 14.91 & 22.50 \\
6 & 0.34587 & 0.105 & 14.91 & 22.50 \\
7 & 0.40927 & 0.172 & 26.23 & 25.00 \\
8 & 0.40936 & 0.172 & 26.25 & 40.36 \\
9 & 0.67935 & 0.252 & 99.70 & 43.98 \\
10 & 0.74820 & 0.258 & 128.29 & \\
\hline
\end{tabular}

\subsubsection{Performance point in the $\mathrm{Y}$ direction}

Results of analysis pushover demand and capacity in the $\mathrm{Y}$ direction are shown in Table 4 and Fig. 11. Based on the results, it is observed that the maximum base shear is $1316.492 \mathrm{kN}$ at the maximum displacement of $30 \mathrm{~mm}$ whereas the spectral acceleration (Sa) and the spectral displacement $(\mathrm{Sd})$ based on the ADRS format are $0.595 \mathrm{~g}$ and $25 \mathrm{~mm}$ respectively for $\mathrm{T}_{\text {eff. }} 0.412 \mathrm{sec}$. The effective damping $\beta_{\text {eff }}$ is 0.159 which is more than the conventional value of 0.05 . So, it shows that structures have more ductility than we have assumed. 


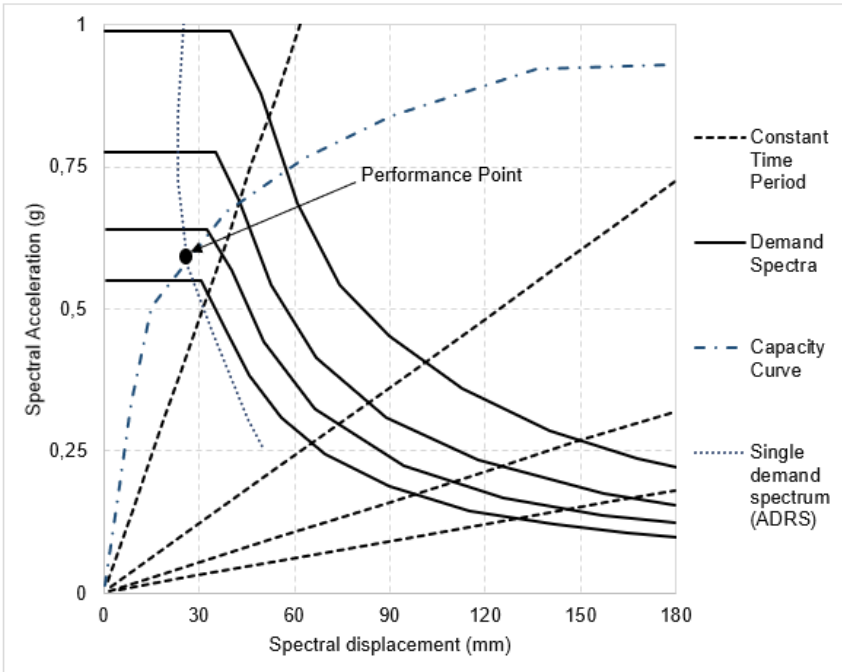

Fig. 9. Capacity spectrum curve in the $X$ direction

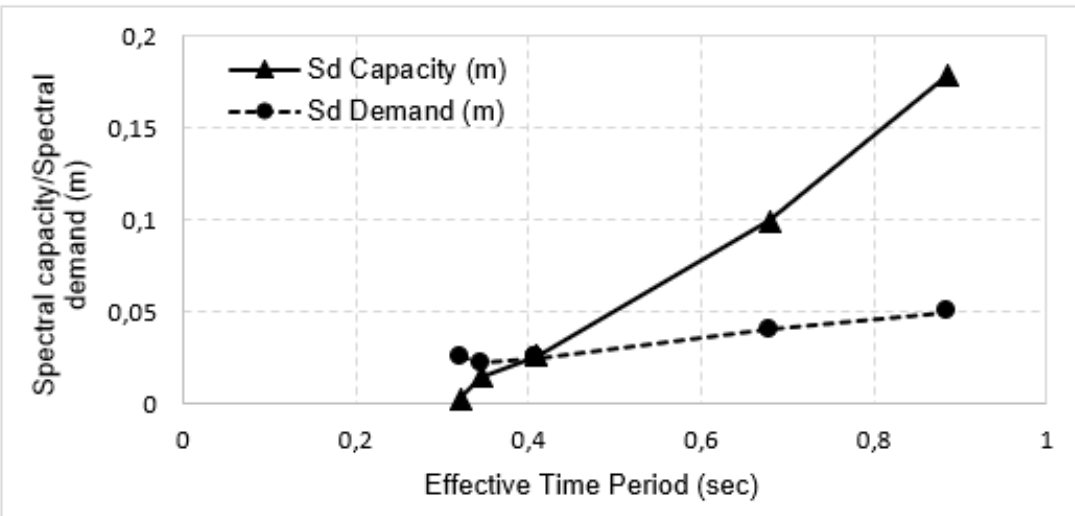

Fig. 10. Spectral capacity and spectral demand in the $\mathrm{X}$ direction

Table 4. Demand and capacity in the $\mathrm{Y}$ direction

\begin{tabular}{ccccc}
\hline \multicolumn{5}{c}{ Demand and capacity in the Y direction } \\
\hline \multirow{2}{*}{ S. No. } & $T_{\text {eff }}$ (Second) & $\beta_{\text {eff }}$ & \multicolumn{2}{c}{ Spectral displacement $\left(\mathrm{S}_{\mathrm{d}}\right)$} \\
\hline 0 & 0.3209 & 0.0500 & 0.00 & Demand $(\mathrm{mm})$ \\
\hline 1 & 0.3209 & 0.0500 & 6.48 & 2.55 \\
2 & 0.3417 & 0.0772 & 1.35 & 2.55 \\
3 & 0.3937 & 0.1484 & 2.22 & 2.49 \\
4 & 0.5424 & 0.2375 & 5.24 & 2.49 \\
5 & 0.6452 & 0.2527 & 8.33 & 3.30 \\
6 & 0.7200 & 0.2580 & 112.23 & 3.82 \\
\hline
\end{tabular}




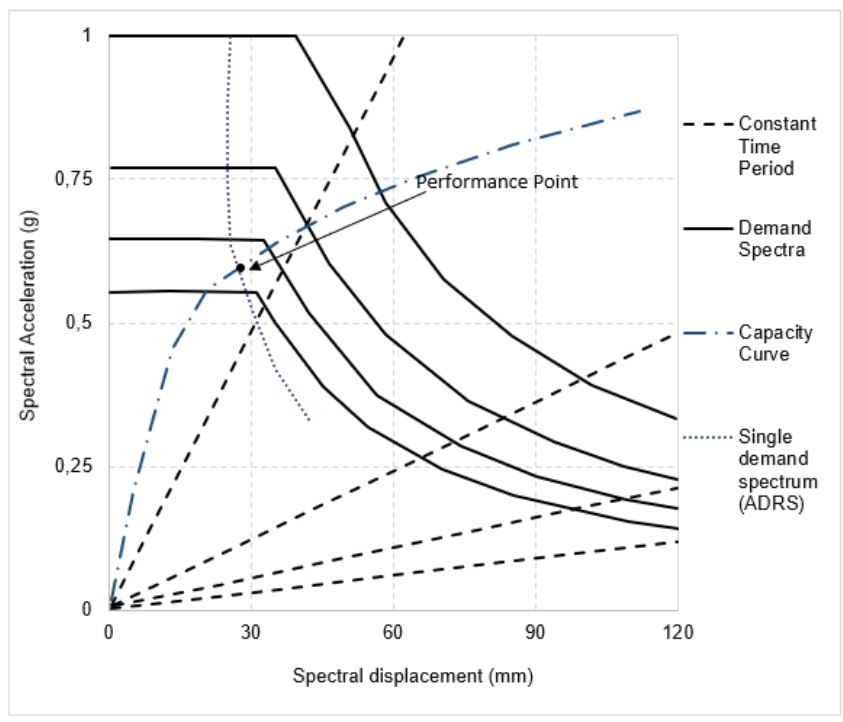

Fig. 11. Capacity Spectrum Curve in the $\mathrm{Y}$ direction

At the effective period of $0.412 \mathrm{sec}$ in $\mathrm{Y}$ direction, the spectral capacity and the spectral demand are calculated from Fig. 12 as $25.9768 \mathrm{~mm}$ and $25.9803 \mathrm{~mm}$ respectively.

Based on results it is observed that the location of the performance point is not satisfying two relationships to prevent the structure from collapse i.e. first, the point is not lying on the capacity spectrum curve to represent the structure at a given displacement and secondly, the point is not lying on a spectral demand curve, reduced from the elastic by 5 percent-damped design spectrum, that represents the nonlinear demand at the same structural displacement.

\subsection{Target displacement using the displacement modification (FEMA 440)}

The target displacement of the bridge structure is calculated in the longitudinal and transverse directions of the bridge structure. The target displacement is determined at the point where the capacity curve intersects the idealized forcedisplacement curve. In the present study, the monitored displacement is considered $320 \mathrm{~mm}$ i.e. up to the collapse of the structure. Below given Tables 5 and 6 give the permissible limit of the monitored displacement in the $\mathrm{Y}$ - and $\mathrm{X}$-directions, respectively.

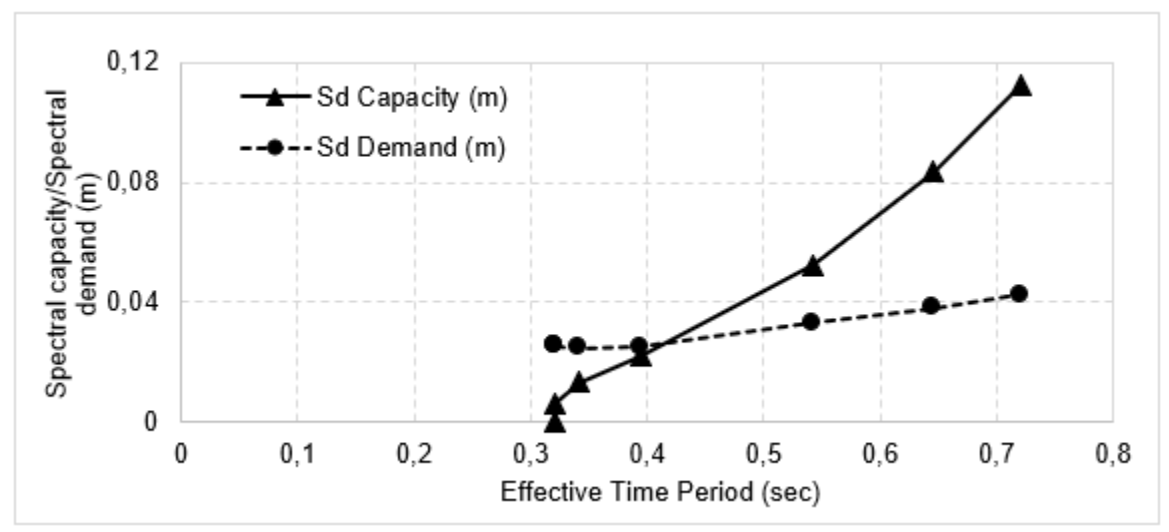

Fig. 12. Spectral Capacity and spectral demand in the $Y$ direction 
Table 5. Base shear vs. monitored displacement in Y-direction

\begin{tabular}{|c|c|c|c|c|c|c|c|c|c|c|c|}
\hline \multicolumn{12}{|c|}{ Pushover curve - push Y } \\
\hline Step & $\begin{array}{l}\text { Displacement } \\
\text { (m) }\end{array}$ & $\begin{array}{c}\text { Base Force } \\
(\mathrm{KN})\end{array}$ & $\begin{array}{l}\mathrm{A} \\
\text { to } \\
\mathrm{B}\end{array}$ & $\begin{array}{l}\text { B } \\
\text { to } \\
\text { IO }\end{array}$ & $\begin{array}{l}\text { IO } \\
\text { to } \\
\text { LS }\end{array}$ & $\begin{array}{l}\mathrm{LS} \\
\text { to } \\
\mathrm{CP}\end{array}$ & $\begin{array}{l}\mathrm{CP} \\
\text { to } \\
\mathrm{C}\end{array}$ & $\begin{array}{l}\text { C } \\
\text { to } \\
\text { D }\end{array}$ & $\begin{array}{l}\text { D } \\
\text { to } \\
\text { E }\end{array}$ & $\begin{array}{l}\text { Beyond } \\
\text { E }\end{array}$ & Total \\
\hline 0 & 0.000067 & 0 & 52 & 0 & 0 & 0 & 0 & 0 & 0 & 0 & 52 \\
\hline 1 & 0.007636 & 665.24 & 51 & 1 & 0 & 0 & 0 & 0 & 0 & 0 & 52 \\
\hline 2 & 0.015987 & 1167.51 & 48 & 3 & 1 & 0 & 0 & 0 & 0 & 0 & 52 \\
\hline 3 & 0.02576 & 1305.86 & 47 & 4 & 1 & 0 & 0 & 0 & 0 & 0 & 52 \\
\hline 4 & 0.05776 & 1392.36 & 47 & 2 & 2 & 1 & 0 & 0 & 0 & 0 & 52 \\
\hline 5 & 0.08976 & 1479.60 & 46 & 0 & 4 & 1 & 1 & 0 & 0 & 0 & 52 \\
\hline 6 & 0.119773 & 1560.41 & 42 & 4 & 4 & 1 & 1 & 0 & 0 & 0 & 52 \\
\hline 7 & 0.119456 & 535.32 & 41 & 4 & 4 & 1 & 1 & 1 & 0 & 0 & 52 \\
\hline
\end{tabular}

Table 6. Base shear vs. monitored displacement in X-direction

\begin{tabular}{|c|c|c|c|c|c|c|c|c|c|c|c|}
\hline \multicolumn{12}{|c|}{ Pushover curve - push X } \\
\hline Step & $\begin{array}{l}\text { Displacement } \\
\text { (m) }\end{array}$ & $\begin{array}{l}\text { Base Force } \\
(\mathrm{KN})\end{array}$ & $\begin{array}{l}\text { A } \\
\text { to } \\
\text { B }\end{array}$ & $\begin{array}{l}\text { B } \\
\text { to } \\
\text { IO }\end{array}$ & $\begin{array}{l}\text { IO } \\
\text { to } \\
\mathrm{LS}\end{array}$ & $\begin{array}{l}\mathrm{LS} \\
\text { to } \\
\mathrm{CP}\end{array}$ & $\begin{array}{l}\mathrm{CP} \\
\text { to } \\
\mathrm{C}\end{array}$ & $\begin{array}{l}\mathrm{C} \\
\text { to } \\
\mathrm{D}\end{array}$ & $\begin{array}{l}\mathrm{D} \\
\text { to } \\
\mathrm{E}\end{array}$ & $\begin{array}{l}\text { Beyond } \\
\text { E }\end{array}$ & Total \\
\hline 0 & 0 & 0 & 52 & 0 & 0 & 0 & 0 & 0 & 0 & 0 & 52 \\
\hline 1 & 0.00002 & 150.22 & 52 & 0 & 0 & 0 & 0 & 0 & 0 & 0 & 52 \\
\hline 2 & 0.00022 & 283.80 & 52 & 0 & 0 & 0 & 0 & 0 & 0 & 0 & 52 \\
\hline 3 & 0.00054 & 1143.43 & 50 & 2 & 0 & 0 & 0 & 0 & 0 & 0 & 52 \\
\hline 4 & 0.00104 & 1146.31 & 50 & 2 & 0 & 0 & 0 & 0 & 0 & 0 & 52 \\
\hline 5 & 0.00180 & 1239.95 & 49 & 3 & 0 & 0 & 0 & 0 & 0 & 0 & 52 \\
\hline 6 & 0.00336 & 1240.12 & 49 & 3 & 0 & 0 & 0 & 0 & 0 & 0 & 52 \\
\hline 7 & 0.00551 & 1391.16 & 46 & 4 & 2 & 0 & 0 & 0 & 0 & 0 & 52 \\
\hline 8 & 0.00760 & 1391.44 & 45 & 4 & 2 & 1 & 0 & 0 & 0 & 0 & 52 \\
\hline 9 & 0.00965 & 1576.53 & 43 & 2 & 4 & 2 & 1 & 0 & 0 & 0 & 52 \\
\hline 10 & 0.01230 & 1640.79 & 41 & 4 & 2 & 2 & 0 & 0 & 2 & 1 & 52 \\
\hline
\end{tabular}

4.3.1. Target displacement parameter in the lateral and longitudinal direction of the bridge

The base shear in the lateral direction at the target displacement of $1373.137 \mathrm{kN}$ is satisfying the cod limit, i.e. not less than $80 \%$ of the effective yield strength of the structure $(80 \%$ of $1212.6142 \mathrm{kN}=$ $970.091 \mathrm{kN})$. The base shear vs. target displacement in Y-direction is shown in Fig. 13. The base shear in the longitudinal direction at the target displacement $1428.492 \mathrm{kN}$ is satisfying the cod limit, i.e. not less than $80 \%$ of the effective yield strength of the structure $(80 \%$ of $1319.93 \mathrm{kN}$ $=1055.2 \mathrm{kN})$. The base shear vs. target displacement in the X-direction is shown in Fig.14. Therefore, it is predicted that the bridge can take more load in the longitudinal direction collapse in the Y-direction. 


\subsection{Sequential failure of structural element}

The sequential failure of the bridge component is shown in Fig. 15. The failure mechanism is calculated at the last step of pushover analysis. The following sequence explains the failure steps of an individual component of the bridge using the pushover analysis of RC bridge:

- E type hinge is formed at the base of the pier, and at its top, $\mathrm{C}$ type hinge (collapse mechanism) is formed.

- At the base of the pier 2, C type hinge (collapse) is formed, and at the top Life Safety Hinge is formed.

- At the top of the pier 3, B type hinge (a yielding mechanism) is formed and there is no hinge formation at the base of the pier

- The longitudinal girder reaches upto the yielding mechanism.

\section{Conclusions}

The present work focuses on the seismic performance analysis of RC bridges using pushover analysis. The bridge shown in the above figure is continued horizontally with its two ends reticent, and that creates inequality of the dynamic analysis of bridges from buildings. Based on the results following points are concluded:
- The modal mass participating ratio in the $\mathrm{X}$ direction (longitudinal direction) is less as compared to the $\mathrm{Y}$ and $\mathrm{Z}$ direction, which shows that the structure is capable to resist the dynamic load in the $\mathrm{Y}$ and $\mathrm{Z}$ directions and we have to ensure that a suitable method should be applied to increase the stiffness in the X-direction.

- At the effective period, spectral displacement is higher than spectral capacity in the $\mathrm{X}$ and $\mathrm{Y}$ direction which shows the need for retrofitting of RC bridge structure.

- Pier 1 fails under crushing at the base this shows that it cannot sustain its self-weight. Also at the top of the pier, a hinge mechanism takes place that leads to the formation of a Collapse Prevention (CP) hinge.

- In Pier 2 collapse prevention hinge is formed at the base, extensive cracking and hinge formation take place in ductile elements whereas limited cracking and splice failure occur in the non-ductile pier. Also at the top of the pier, Life Safety (LS) type hinge is formed in which crack is formed at the microscopic level.

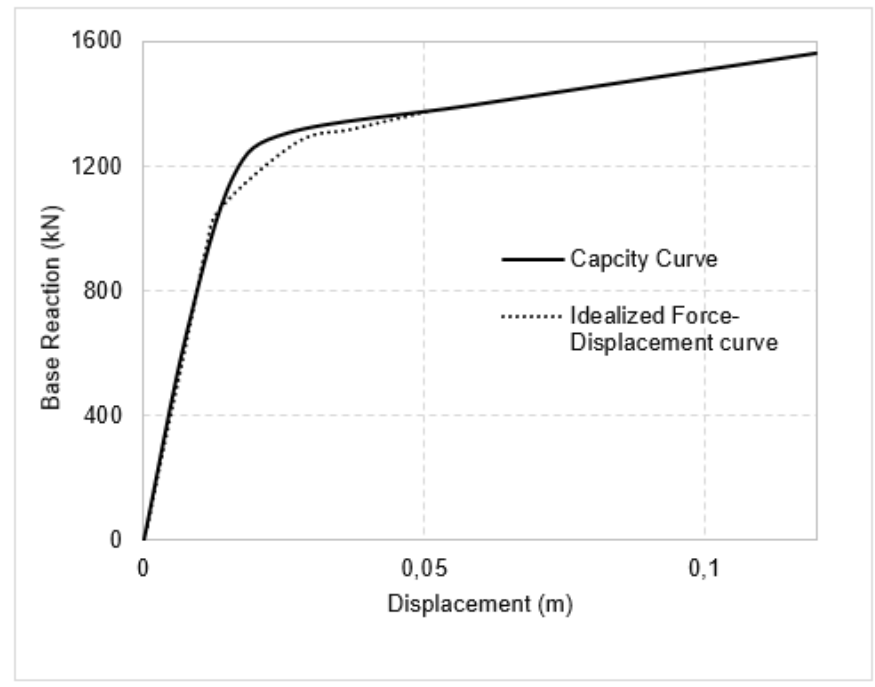

Fig. 13. Base shear force vs displacement using FEMA 440 in the $\mathrm{Y}$ direction 


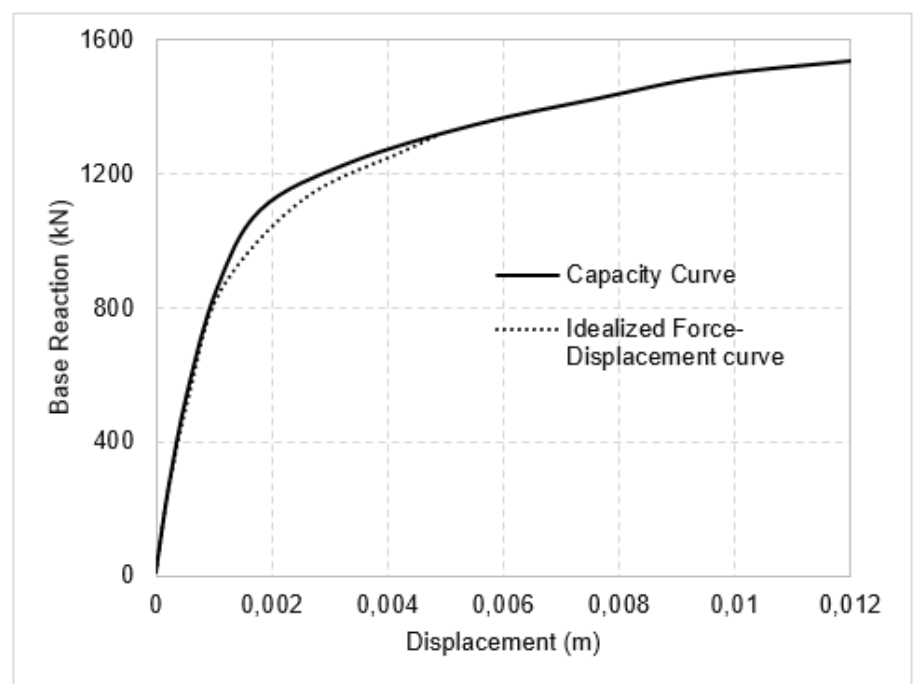

Fig. 14. Base shear force vs displacement using FEMA 440 in the $\mathrm{X}$ direction

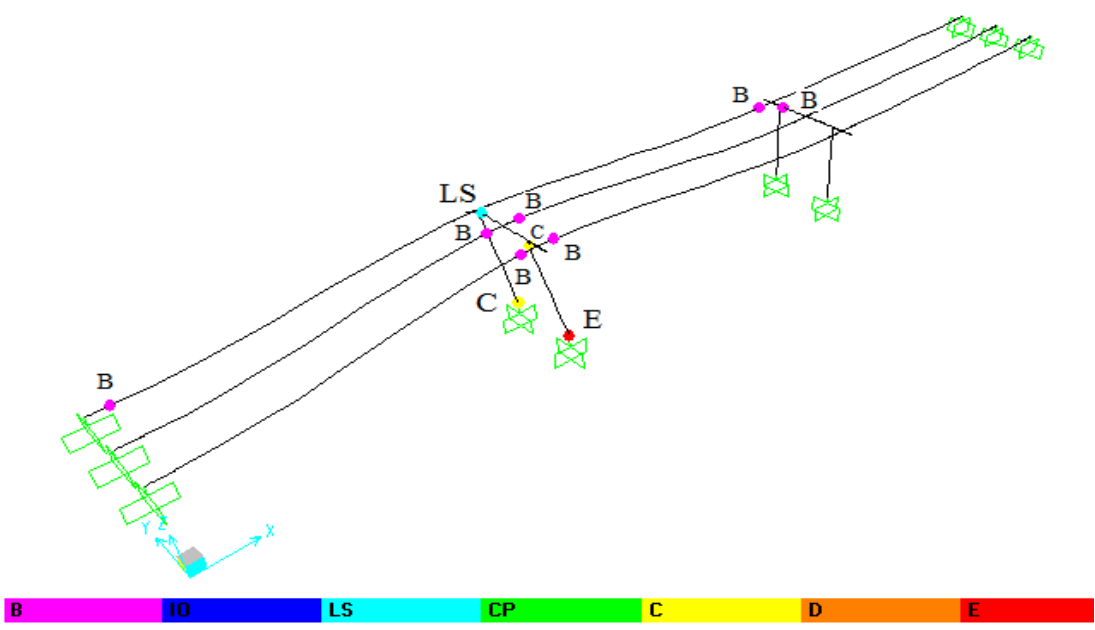

Fig. 15. Hinges formation in the structural element

- Using Displacement Modification Method (FEMA 440), for collapse prevention (CP)level, the monitored displacement in the $\mathrm{Y}$ direction is $119.77 \mathrm{~mm}$ and the target displacement is $51 \mathrm{~mm}$. To re-strengthening the structure for the $\mathrm{CP}$ performance point we have to control the maximum displacement of the structure up to the target displacement.

\section{Declaration of conflicting interests}

The author(s) declared no potential conflicts of interest concerning the research, authorship, and/or publication of this article.

\section{Acknowledgments}

The authors would like to acknowledge the late Dr. Kailash Narayan who was a Professor in the Department of Civil Engineering IET, Lucknow, India to motivate and guide us during this work.

\section{References}

[1] Han Q, Du X, Liu J, Li Z, Li L, Zhao J (2009) Seismic damage of highway bridges during the 2008 Wenchuan earthquake. Earthquake Engineering and Engineering Vibration 8(2): 263273. 
[2] Ranf RT, Eberhard MO, Malone S (2007) Postearthquake prioritization of bridge inspections. Earthquake Spectra 23(1): 131-146.

[3] Chopra AK, Goel RK (2002) A modal pushover analysis procedure for estimating seismic demands for buildings. Earthquake Engineering \& Structural Dynamics 31(3): 561-582.

[4] Abeysinghe RS, Gavaise E, Rosignoli M, Tzaveas $\mathrm{T}$ (2002) Pushover analysis of inelastic seismic behavior of Greveniotikos Bridge. Journal of Bridge Engineering 7(2): 115-126.

[5] Applied Technology Council (ATC). Seismic evaluation and retrofit of concrete buildings. Applied Technology Council, Report ATC-40. Redwood City, 1996.

[6] Sung YC, Liu KY, Su CK, Tsai IC, Chang KC (2005) A study on pushover analyses of reinforced concrete columns. Structural Engineering and Mechanics 21(1): 35-52.

[7] Kappos AJ, Paraskeva TS, Sextos AG (2005) Modal pushover analysis as a means for the seismic assessment of bridge structures. Proceedings of the 4th European Workshop the Seismic Behaviour of Irregular and Complex Structures.

[8] Paraskeva TS, Kappos AJ, Sextos AG (2006) Extension of modal pushover analysis to seismic assessment of bridges. Earthquake Engineering \& Structural Dynamics 35(10): 1269-1293.

[9] Banerjee S, Shinozuka M (2007) Nonlinear static procedure for seismic vulnerability assessment of bridges. Computer-Aided Civil and Infrastructure Engineering 22(4): 293-305.

[10] Muljati I, Warnitchai P (2007) A modal pushover analysis on multi-span concrete bridges to estimate inelastic seismic responses. Civil Engineering Dimension 9(1): 1-33.

[11] Pinho R, Casarotti C, Antoniou S (2007) A comparison of single-run pushover analysis techniques for seismic assessment of bridges. Earthquake Engineering \& Structural Dynamics 36(10): 1347-1362.

[12] Paraskeva TS, Kappos AJ (2008) An improved multimodal procedure for deriving pushover curves for bridges. The 14th World Conference on Earthquake Engineering, Beijing, China.

[13] Shattarat NK, Symans, MD McLean DI, Cofer WF (2008) Evaluation of nonlinear static analysis methods and software tools for seismic analysis of highway bridges. Engineering Structures 30(5): 1335-1345.
[14] Paraskeva TS, Kappos AJ (2009) Further development of a multimodal pushover analysis procedure for seismic assessment of bridges. Earthquake Engineering \& Structural Dynamics 39(2): 211-222.

[15] Shafiei-Tehrany R, ElGawady M, Coffer W (2011) Pushover analysis of I-5 RAVENNA bridge. Electronic Journal of Structural Engineering 11(1): 32-41.

[16] Beheshti-Aval SB, Jahanfekr E (2015) Modification of displacement coefficient method in estimation of target displacement for regular concrete bridges based on ASCE 41-06 standard. Civil Engineering Infrastructures Journal 48(1): 0112.

[17] Ojha Mishra A, Firoj M, Narayan K (2017) Non linear static analysis of dual RC framed structure. International Research Journal of Engineering and Technology 4(9): 831-838.

[18] Patil DM, Bhargava R, Khare RK (2019) Performance-based seismic evaluation of different concrete bridges. International Journal of Applied Engineering Research 14(11): 2799-2805.

[19] Murdiansyah L, Permata R, Essen D (202) Modal pushover analysis on reinforced concrete arch bridge to estimate seismic responses. E3S Web of Conferences, 156: 1-6.

[20] Maheshwari BK, Firoj M (202) Equivalent linear spring-dashpot model for embedded foundations of NPP. The 17th World Conference on Earthquake Engineering (17WCEE), Sendai, Japan, pp: 1-12.

[21] Bergami V, Nuti C, Lavorato D, Fiorentino G, Briseghella B (2020) IMPA $\beta$ : Incremental Modal Pushover Analysis for Bridges. Applied Sciences 10(12): 1-24.

[22] Applied Technology Council (ATC). Improvement of nonlinear static seismic analysis procedures. Rep. No. FEMA-440, 2005, Washington, D.C.

[23] Victor DJ (2017) Essentials of Bridge Engineering. Oxford and IBH Publishing.

[24] IRC 6-2014. Standard Specifications and Code of Practice for Road Bridges, Section II, loads and stresses, The Indian Roads Congress, 2014, New Delhi.

[25] Indian Standard, 1893-2016. Criteria for earthquake resistant design of structures. Indian Standards Institution, 2016, New Delhi.

[26] Firoj M, Singh SK (2018) Response spectrum analysis for irregular multi-storey structure in seismic zone V. 16th Symposium on Earthquake Engineering, IIT Roorkee, India, pp: 1-9. 
[27] Pundrik P, Bahuguna A, Firoj M (2020) Near fault and far fault seismic analysis of concrete gravity dam. Journal of Hydraulic Structures 6(2): 56-79.

[28] Firoj M (2017) Performance of Reinforced Concrete Bridge Structure using Pushover Analysis, MSc Thesis. Institute of Engineering and Technology IET, Lucknow.
[29] AASHTO-2010. Standard specifications for highway bridges, American of state Highway and Transportation Officials Inc., 2010, Washington, DC.

[30] Chang KC, Chang KW, Tsai MH (2000) Seismic performance of highway bridges. Earthquake Engineering and Engineering Seismology 2(1): 5577. 